胃癌を契機に発見された横隔膜弛緩症を伴う成人胃軸捻転症の 1 例

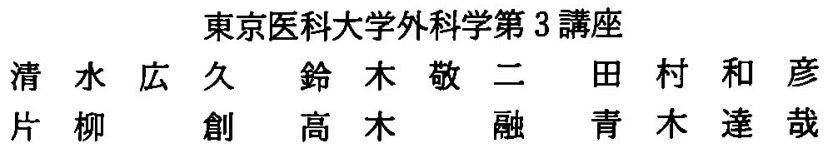

胃軸捻転症の成人発症例は稀である.今回，われわれは成人の横隔膜驰緩症が誘因と なった胃軸捻転症を合併した胃癌に対し，外科的治療を行った 1 例を経験したので報告 する. 症例は69歳, 男性, 健診にて施行した上部消化管造影にて異常陰影を指摘され, 当院を受診した。胃内視鏡検查にて胃瘤と診断され当院入院となった．胸部単純X線写 真, 上部消化管造影にて横隔膜弛䋸症を伴う胃軸捻転症（間膜軸性）と診断, 開腹手術 を施行した。手術は幽門側胃切除, D-2 郭清, Billroth-I 法再建および横隔膜縫縮術(重 層形成法）を行った。術後 5 年を経過したが再発を認めず, 経過良好である.

索引用語：胃軸捻転症, 横隔膜弛緩症, 胃癌

\section{緒 言}

胃軸捻転症は横隔膜ならびに消化器の先天性異常を 伴う新生児や小児に好発する疾患であり ${ }^{31}$, 成人発症 例は稀である。.今回われわれは成人の横隔膜驰緩症か 誘因となった胃軸捻転症を合併した胃癌に対し，外科 的治療を行った症例を経験したので，若干の文献的考 察を加えて報告する。

$$
\text { 症例 }
$$

患者：69歳, 男性.

主訴：特になし。

既往歴：1995年より糖尿病。

家族歴：特記すべきことなし。

現病歴：1999年 4 月の検診にて上部消化管造影施行 し, 胃前庭部に異常陰影指摘され, 当院受診となり胃 内視鏡施行. 胃前庭部前壁の胃潰瘍の診断にて外来 follow. 3 力月後再度, 内視鏡施行し生検にて高分化型 腺癌の診断にて入院となる。

入院時現症：身長 $155 \mathrm{~cm}$, 体重 $53 \mathrm{~kg}$, 血圧 $125 / 80$ $\mathrm{mmHg}$, 脈拍70回/分, 貧血, 黄㾝を認めず, 胸部所見 では左下肺野領域に呼吸音の低下を認め, 腹部所見て は異常を認めなかった。

入院時検査所見：血清生化学データ上異常を認め

2005年 8 月 9 日受付 2005 年 9 月21日採用

〈所属施設住所〉

₹160-0023 東京都新宿区西新宿 6-7-1
ず, 腫場マーカーも正常. 心電図では, 単発の PVCを 認め, 呼吸機能は正常であった.

胸部単純 $\mathbf{X}$ 線検查所見：左横隔膜は著しく挙上し ており，左横隔膜下に㹡張した胃泡を認め，綎隔の右 方偏位を認めた（図 1 ).

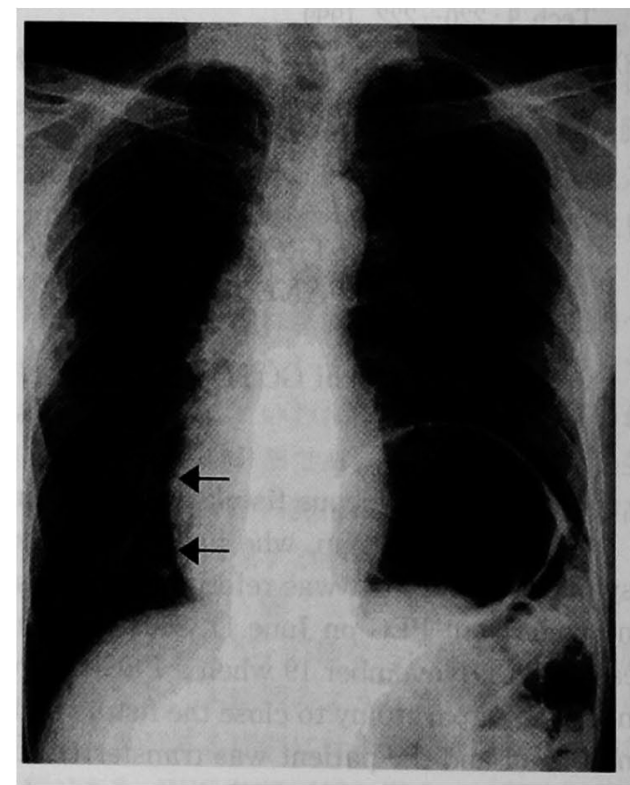

园 1 胸部単純 $\mathrm{X}$ 線写真：左横隔膜の挙上抽よ び横隔膜下に㹡張した胃泡を認める。絴隔は右

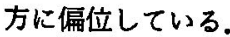




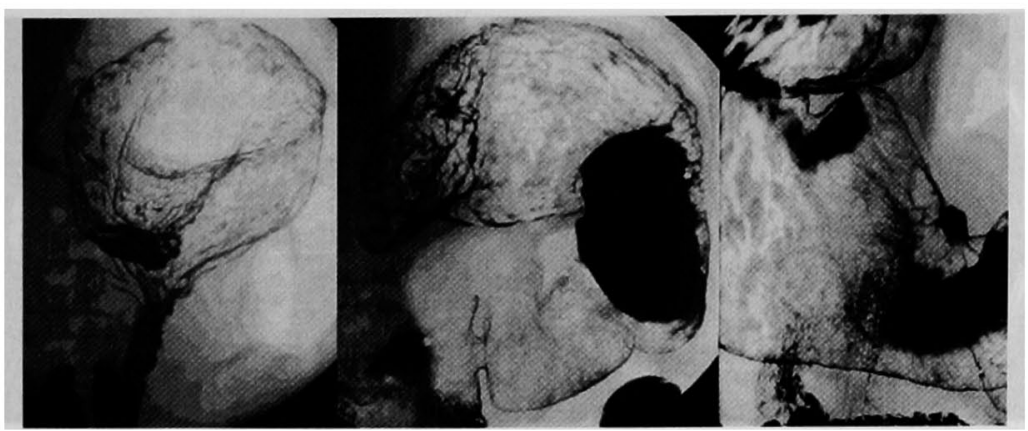

図 2 上部消化管造影写真：左，中)食道胃接合部が尾側腹側に偏位し胃の倒立像 を認める. 右) 胃前庭部小繁側前壁奇りに全周性の周堤を伴った辺縁不整なバリ ウム斑を認める。

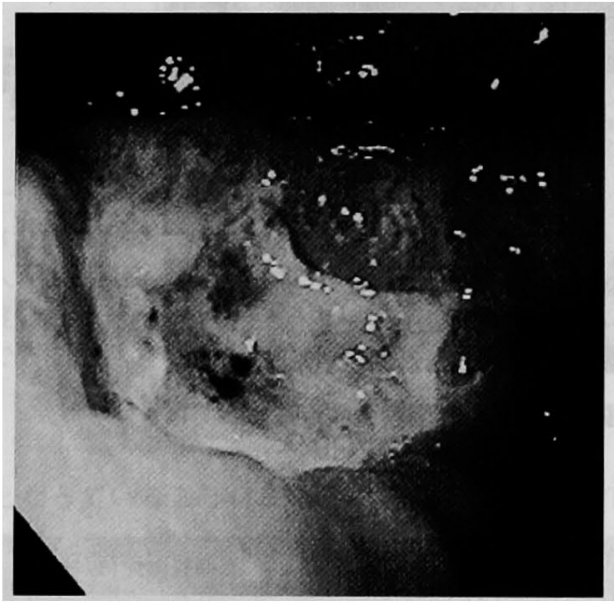

图 3 胃内視鏡写真：胃前庭部に急峻な立ち上 がりを示す周堤に囲まれた辺緑不整な謴暍性 病変を認める.

上部消化管造影検査所見：食道胃接合部が尾側腹側 に偏位し胃の倒立像を認めた(図 2 左，中)。また，胃 前庭部小側前壁寄りに全周性の周堤を伴った辺縁不 整なバリウム斑を認めた（図 2 右）。

胃内視鏡検查所見：胃前庭部に急峻な立ち上がりを 示す周堤に囲まれた辺縁不整な謴瘍性病変を認め, 生 検の結果高分化型腺癌と診断された（図 3 ).

CT 検査所見：著明に拡張した胃を認め，リンパ節 の腫脹や他蔵器転移を疑わせる所見は認めなかった (图 4).

以上の所見より，横隔膜弛緩症，間膜軸性の胃軸捻 転症および胃前庭部の Type 2進行胃癌の術前診断に より，1999年11月 9 日手術を施行した。

手術所見：上腹部正中切開にて開腹すると弛緩した
横隔膜のスペース（図 5 左）に胃体部が宿入し，間膜 軸性の捻転を認めた．また横隔膜の筋層欠如や菲薄化 は認められず, 後天性発生が推測された。手術は幽門 側胃切除, D-2郭清, Billroth-I 法再建, 胆藮摘出術を 施行．横隔膜弛緩症に対しては重層形成法により縫縮 を行った（図 5 右）。

病理所見：Less $3.5 \times 1.4 \mathrm{~cm}$ III + IIc T1 (SM) tubl INF $\alpha$ ly0 v0 n0 ow (-) aw (-).

術後経過：術後経過良好で，退院時胸部単純X線検 査では，術前に較べて約 2 助間分の横隔膜の低下を認 めた(図6). 第30病日にて退院し，5年経過した現在， 再発を認めていない.

\section{考察}

胃軸捻転症とは胃が異常な捻れにより正常の位置よ り変位変形した状態である1)．軸捻の方向により噴門 と幽門を結ぶ軸を中心に回転する蔵器軸性と，本症例 のように胃大彎の中央と肝門部を結ぶ線を軸として回 転する間膜軸性の 2 つに分類される（図 7 ) 2 .

胃軸捻転症は新生児および小児に発生しやすく，そ の頻度は0.15〜0.23\%との報告がある ${ }^{3)-5)}$. その発生 原因には，胃固定靶帯の固定不全および靯帯欠如なら びに他蔵器との複合奇形などがあげられている3～. 一方，成人（18歳以上）例における本疾患の発生機序 は，新生児および小児のそれと若干の差異を認め, Sephenson ら ${ }^{6)}$ は, 文献の $15 \%$ は横隔膜性のものであり， うち $1 / 3$ は横隔膜弛緩症であると述べている. 本邦て は，2004年までの成人胃軸捻転症の報告76例のうち 37 例の発生要因が横隔膜疾患であり，うち14例が横隔膜 弛䋸症であった（図 $8 \mathrm{a}$ )。また本症例のように胃癌を 伴ったものは 4 例でそのうち 3 例が本症例と同様に間 膜軸性のものであり，胃癌合併症例全例軸捻転症の発 


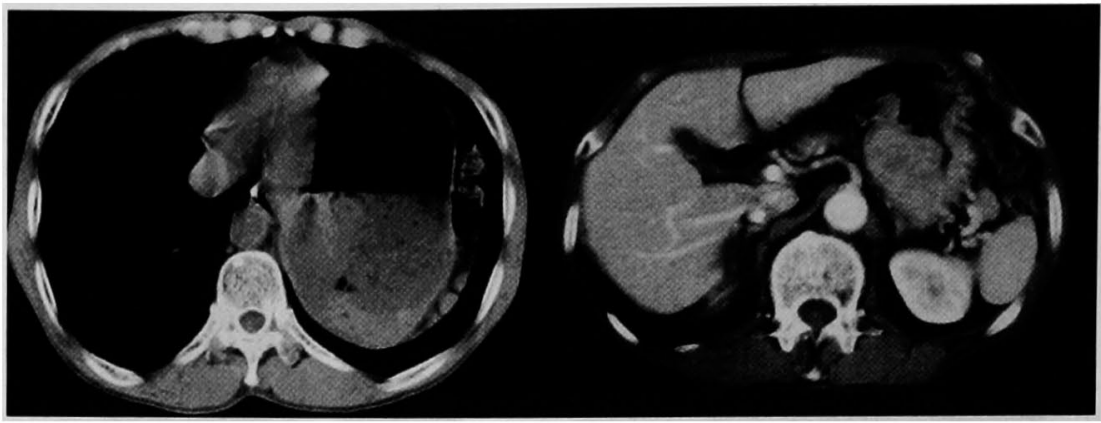

図 4 胸腹部 CT 写真 : 著明に拡張した胃を認め,リンパ節の腫脹や他臓器転移を疑わせ る所見は認めない。

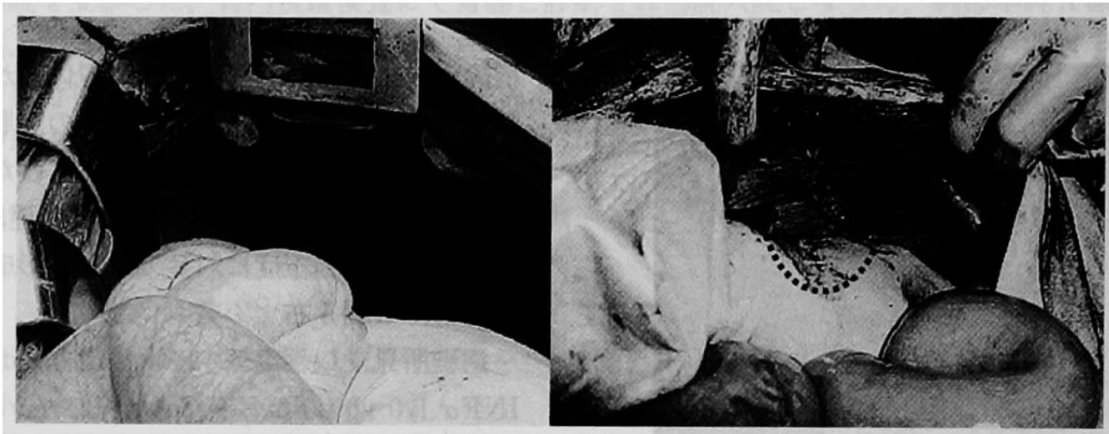

図 5 術中写真 : 左) 弛緩した横隔膜のスペースを認めた。右) 横隔膜弛緩症に対しては 重層形成法により縫縮（点線囲み部）を行った。

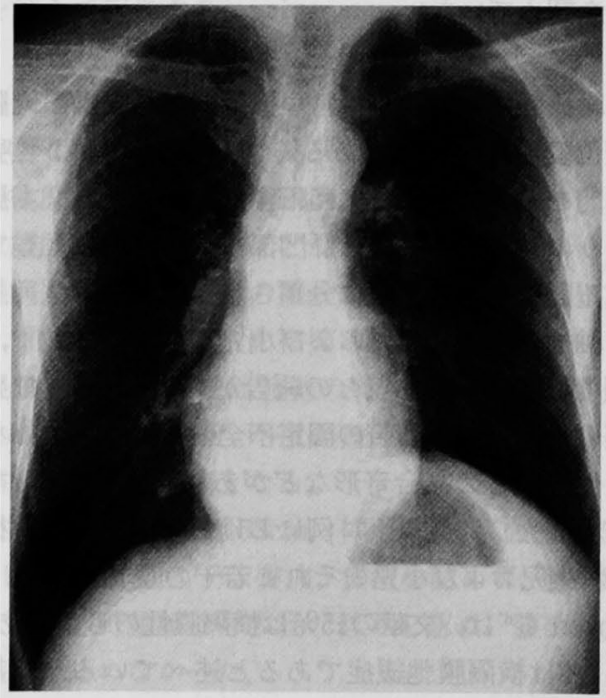

図 6 術後胸部単純 $X$ 線写真：退院時胸部単純 $\mathrm{X}$ 線写真では, 術前（図 1 ) に較べて約 2 肋間 分の横隔膜の低下を認めた.

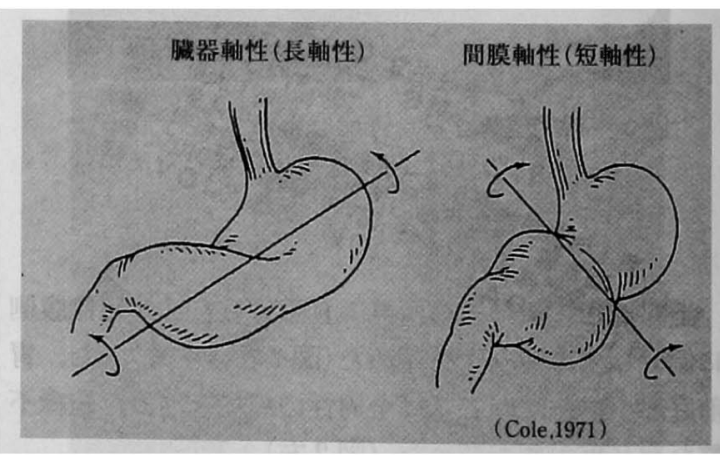

図 7 䑏器軸性捻転と間膜軸性捻転：噴門と幽門を結ぶ 軸を中心に回転する荿器軸性と，胃大管の中央と肝門 部を結ふ線を軸として回転する間膜軸性に分類され る.

生要因となるような合併疾患を有していた。

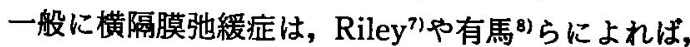
病因的に先天性と後天性に分類され，先天性発生は胎 生期の横隔膜形成に際し, 筋層の発育欠如ないし不完 全によるとされ，そのため横隔膜中心部が菲薄化し膜 


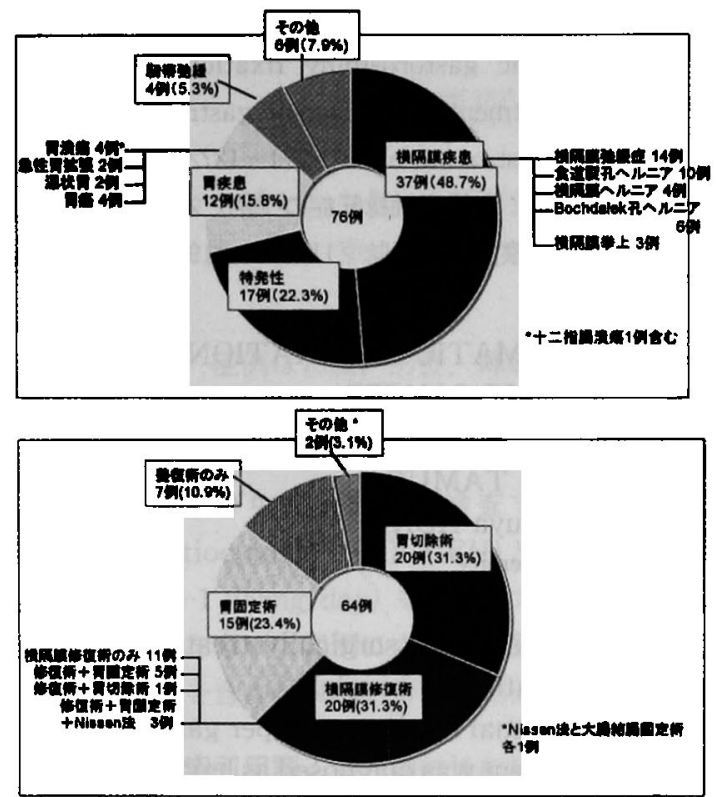

図 8 成人胃軸捻転症の発生要因 (a) とその治癔 (b)：成 人胃軸捻転症の発生要因では横隔膜疾患がもっとも高頻 度である．開腹術症例のうち整復術のみは 7 例 (10.9\%) であった。

様となっていることが多い，一方，後天性発生では経 過の長いものを除き横隔膜の菲薄化は稀である. 本例 は横隔膜の筋層欠如, 菲薄化は認められず, 後天性発 生が推測された。

症状としては, 吐物なき嘔吐反射, 強い上腹部の疼 痛と膨満, 胃管扱入困難の 3 つが急性の胃軸捻転症の 際現れる代表的症状で, Borchardt $の 3$ 主徵と呼ばれ ているッ゙.また嚾下障害, 腹部膨満, 心窝部痛が認めら れるものを慢性, または慢性反復性と呼んでいる。

治療方法としては，急性型では胃壊死の危険性があ り緊急手術の適応となる．慢性型では，その原因がは つきりしているものでは手術適応とされ(0), Creedon ${ }^{11}$ は無症状でも積極的に原因の除去を図るへ きとしている，手術は軸捻転を解除して胃の固定を行 う. 固定法としては, Sephenson らの付提唱する肝円索 と胃前壁わよび肝緑と胃小留の固定. 小坂ら ${ }^{12)}$ の胃幽 門部後壁と横行結腸間膜起始部の縫着, 沢口ら ${ }^{13)}$ の胃 前庭部と横隔膜下面の縫合があるが，近年では，内視 鏡下, 腹腔鏡下にて捻転を整復し，ガストロボタンを 使い内視鏡で経皮的に胃を固定する術式などが行われ ている ${ }^{14)}$. 過去の報告例では76例中64例に開腹術が施
行され, 開腹術の術式は, 胃切除術, 横隔膜修復術が それぞれ20例と多く，次いで周固定術が15例，整復術 のみは 6 例であった (図 $8 \mathrm{~b}$ )。谷田 ${ }^{15}$ ) は, 胃軸捻転症 の小児例において，整復術のみのために $13.8 \%$ に症状 の再発をみたと報告しており，整復術のほか追加手術 の必要性を示唆している.

自験例では, 胃癌の治療として幽門側胃切除, Billroth-I 法再建を行うことにて残胃の固定とし，胃軸 捻転の原因となった横隔膜弛㖃症に対して重層形成法 を行い経過良好であるが, 胃軸捻転症の手術について は，いまだ確立した術式はなく今後の検討課題と考え 3.

\section{結語}

胃癌を契機に発見された横隔膜驰緩症を伴う成人胃 軸捻転症という比較的稀な症例を経験したので，文献 的考察を加えてここに報告した。

\section{文献}

1) 金沢暁太郎, 安田是和, 佐藤知行他：消化管症候 群, 胃軸捻症. 別冊日本臨牀領域別症候群シリー ス, 5 , 消化管症候群 (上巻), 日本臨林社, 大阪, 1994, p404-410

2) Von Heberer $\mathrm{H}$ : Bolvulus des Marens bei Carcinom. Dtsch Chir 115 : 497-532, 1912

3）浅井 '毅, 藤本泰久, 西野裕二他：急性胃軸捻転 症の 2 例。日臨外会誌 $44: 265-269,1983$

4）東 義治：胃軸捻転症, 胃・十二指腸㵋瘍, 胃破 裂。小児外科 $18: 87,1986$

5）平田展章：小児急性胃軸捻転症の 1 例. 小児外科 $19: 1245,1987$

6) Sephenson RH, Hopkins WA : Volivulus of the stomach complicating eventration of the diaphragm. Am J Gastroenterol 41 : 225-234, 1964

7) Riley EA : Idiopathic diaphragmatic paralysis: A report of eight cases. Am J Med 32 : 404416, 1962

8）有馬速水：横隔膜驰㖃症. 小児科 $7: 116,1967$

9) Borchardt $\mathrm{M}:$ Zur Pathologic und Therapic des Magenvoluvulus. Arch Klin Chir 74 : 243-248, 1904

10）金井武彦：胃軸挖転について. 胃と腸 $4 ： 731-$ 742, 1959

11) Creedon PJ : Voluvulus of the stomach : Report of a case with compliocation. Am J Surg 110: 964-966, 1965 
12）小坂 進，素谷 宏：胃軸捻転症に対する胃固定 術一胃幽門部後壁, 横行結腸間膜起始部縫着法. 手術 $26: 1075-1079 ， 1972$

13）沢口重徳, 秋山 洋, 北村 倰他：小児のいわゆ る特発性胃軸捻転症の発生生理と治療. 日外会誌 $76: 771-772,1975$
14) Ghosh S, Palmer KR: Double percutaneous endoscopic gastorostomy fixation: An effective treatment for recurrent gastric volvulus. Am J Gastroenterol 88: 1271-1272, 1993

15）谷田 秀：小児胃軸捻転症の 1 例と本邦報告例の 統計的観察。米子医誌 $11: 211,1983$

\title{
A CASE OF GASTRIC VOLVULUS WITH DIAPHRAGMATIC RELAXATION IN AN ADULT PRESENTED WITH GASTRIC CANCER
}

\author{
Hirohisa SHIMIZU, Keiji SUZUKI, Kazuhiko TAMURA, \\ So KATAYANAGI, Yu TAKAGI and Tatsuya AOKI \\ Department of Surgery, Tokyo Medical University
}

It is rare that gastric volvulus occurs in adults. This paper presents a surgically treated case of gastric cancer with gastric volvulus caused by diaphragmatic relaxation in an adult.

A 69-year-old man was seen at the hospital because of an abnormal shadow on upper gastrointestinal study at a medical checkup. Following gastric endoscopy, the patient was diagnosed as having gastric cancer and admitted to the hospital. Chest plain $\mathrm{x}$-ray film and upper gastrointestinal series provided the diagnosis of gastric volvulus (mesenterioaxial volvulus) associated with diaphragmatic relaxation, and a laparotomy was carried out. Operative procedures included distal gastrectomy, D2 dissection, Billroth- I reconstruction and plication of the diaphragm (stratification method). The patient makes satisfactory progress and has no signs of recurrence, as of 5 years after the operation. 